\title{
Открытие отделений русских банков в Великом княжестве Финляндском в начале XX в.
}

\begin{abstract}
Аннотахия. Автор подробно рассматривает прочесс открытия в Великом княжестве Финляндском в начале ХХ в. отделений Государственного банка Российской империи и частных русских банков, который являлся одним из значимых шагов на пути финансовой интеграиии практически автономного на тот момент крал 8 Российскую империю. Этот прочесс в целом не бъл доведен до значимых результатов из-за начавшейся Первой мировой войны, однако в некоторой степени смог раскрыть свой потенииал. В основе этого исследования лежит изучение архивов канчеларий генерал-губернатора и статс-секретариата Великого княжества Финляндского, анализ которых дал возможность выявить причины, основные вехи и итоги открытия в Финляндии отделений русских банков. Многие источники из этих архивов впервые вводятся в научный оборот. Новизна исследования заключается в изучении попытки не силовой, а финансовой интеграчии - с помощъю открытия отделений русских банков - окраины Российской империи, все более удалявшейся от нее как в культурном, так и в экономическом плане. Автор в данной работе рассмотрел, почему эта попътка осталасъ безуспешной и бъла ли возможность реализовать ее в полной мере.
\end{abstract}

Ключевые слова: Великое княжество Финляндское, финансы, интеграиия, Государственный банк России, статссекретариат, экономическая история, русско-финские отношения, отделения Государственного банка, частные русские банки, начиональные окраины империи.

Abstract. The process of opening the State Bank of Russia and private Russian banks branches in the Grand Duchy of Finland in the early 20th century represented one of the most important steps to financial integration of an almost autonomous region into the Russian Empire. This process experienced some troubles and problems related to the Finnish opposition and complicated domestic situation in Russia. It had not shown any results because of the start of the First World War. However, to some extent, it managed to unlock its potential. This research has become possible with the help of office archives of GovernorGeneral and stats-secretariat of the Grand Duchy of Finland. Their thorough examination allowed the uncovering of factors, main steps and results of Russian Bank operations in Finland. In addition to the fact that this article is the first to introduce some of the sources, it can also give an indepth understanding of complex relations between the Russian government and the Grand Duchy. The study of an attempt to financially rather than forcefully integrate periphery, that was moving further and further away in cultural and economic terms, is extremely important for contextualizing and redefining the already existing ideas of core actions towards newly annexed territories in the pre-revolutionary time.

Key words: the Grand Duchy of Finland, finance, integration, State Bank of Russia, stats-secretariat, economic history, Russian-Finnish relations, branches of State bank, private Russian banks, national peripheries of Empire.

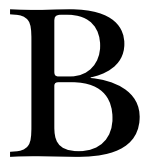

1914 г. в Великом княжестве Финляндском, в г. Выборге открылось отделение Государственного банка Российской империи - главного правительственного банка, который выполнял также и функции главного эмиссионного центра, регулировавшего денежное обращение. Открытие его отделения в Финляндии - не столь значительное событие в масштабах империи - было, однако же, важной вехой в столкновении как политических, так и экономических интересов Российской империи и Великого княжества Финляндского. Казалось бы, существование отделения государственного банка страны на одной из ее окраин подразумевалось само собой, особенно в начале $\mathrm{XX}$ в., когда развитие финансовой сферы достиг- 


\section{Исторический журнал: научные исследования № 4 (34) • 2016}

DOI: $10.7256 / 2222-1972.2016 .4 .19734$

ло определенного уровня. Но в Великом княжестве Финляндском сложилась особая ситуация.

К началу ХХ в. Великое княжество Финляндское уже почти столетие было частью Российской империи, однако дарованная ему императором Александром I изначально достаточно широкая степень автономии - собственная конституционная система (Закон о форме правления Швеции 1772 года), отличный от империи григорианский календарь, свое законодательство и парламентское представительство - позволила княжеству к концу XIX в. достигнуть значительной самостоятельности и в экономической сфере. В частности, в это время у Финляндии уже был свой центральный банк - Финляндский банк, - а также имелись своя валюта, своя таможенная служба, торговые и финансовые связи с европейскими странами $[1 ; 2]$.

В конце XIX в. российское правительство начало проводить политику постепенной интеграции княжества в Российскую империю, в том числе интеграции финансовой. С 1890-х гг., задолго до первой попытки открыть в Финляндии отделения Государственного банка, начали обсуждаться и вырабатываться проекты по объединению денежной и таможенной систем. Само же отделение задумывалось как средство внедрения и популяризации среди местного населения русских денежных знаков, что в дальнейшем облегчило бы денежную реформу. Соответственно, открытие отделений Государственного банка в Финляндии являлось бы очередным и очевидным шагом к объединению финансовых сфер империи и ее окраины.

Главным препятствием для осуществления данной политики являлось то, что в Финляндии к тому моменту уже успешно складывалась относительно самостоятельная финансовая система, более склонная ориентироваться на европейские рынки и инвестиции [3]. Разумеется, значительная доля финского импорта и экспорта была связана с российским рынком, однако, как показывает исследование индексов фондовых бирж Европы, России и Финляндии предвоенных лет, последняя больше зависела от европейского, чем от российского финансового рынка [4]. В совокупности с развитием национальной идеи, занимавшей умы финляндского общества того времени, очевиден курс Финляндии на увеличение своей автономии, что приводило к конфликту интересов правительства Российской империи и финляндского сената. Исследование процесса открытия отделения Государственного банка как частного случая столкновения этих интересов позволяет как показать взаимодействие этих двух органов власти, так и попытаться оценить возможности имперской политики, которой было во многом не суждено осуществится из-за революции 1917 г.

Этот вопрос в отечественной историографии рассматривался в работах И. М. Бобович [5], Б. В. Ананьича [6], Е. А. Правиловой [7], однако исследователи ограничивались описанием неудачи с открытием первого отделения, не затрагивая вопрос об открытии через несколько лет второго отделения в Выборге. Именно этот процесс и рассматривается в данной статье.

Процесс открытия отделений российского Центрального банка растянулся на 13 лет с большим перерывом и проходил в два этапа. Первый этап - открытие отделения в Гельсингфорсе (совр. Хельсинки). Начался он с того, что министр финансов в 1901 г. возбудил вопрос о распространении действий Государственного банка на Финляндию. Он мотивировал свое предложение следующими соображениями: во-первых, открытие отделения Государственного банка на территории Финляндии будет способствовать водворению в край русских денежных знаков, во-вторых, позволит ознакомиться с условиями и особенностями денежного обращения в крае - и то и другое было немаловажно в свете все еще обсуждаемого проекта по объединению денежных систем. В-третьих, предполагалось, что такое отделение должно пойти на пользу русским промышленникам и торговцам, которые тогда смогут брать кредиты на принятых в империи условиях [8, л. 1-3]. Видно, что помимо очевидно политических мотивов, министр усматривал и экономические выгоды от открытия такого отделения. Нельзя сказать, что такие ожидания были чисто умозрительными. Например, в письме финляндскому генерал-губернатору Н. И. Бобрикову купец Григорий Григорьев от лица русских купцов жаловался на притеснения от шведской партии в Гельсингфорсе, которая ставила препятствия к получению кредита, из-за чего многие купцы хотели прекратить торговлю, а также утверждал, что банки на рубли не меняют («если захочешь разменять на русскую монету для перевода через Казначейство хоть 5000 марок, то отказываются, говоря, что у них нет таких денег») и русских денег не берут [8, л. 29-31].

Помимо прочего, это свидетельство может указывать на то, что частный бизнес в Финлян- 


\section{Экономическая история, история предпринимательства}

DOI: $10.7256 / 2222-1972.2016 .4 .19734$

дии (по крайней мере, в Гельсингфорсе) на тот момент эффективно сопротивлялся появлению на внутреннем рынке русских конкурентов.

Предложение министра финансов было направлено генерал-губернатором в финляндский сенат, правительственный орган Великого княжества Финляндского. Полученный от сената отзыв был уклончиво негативным [8, л. 5-7]. В целом финляндское общество воспринимало курс на политическую и экономическую интеграцию как ограничение их законной автономии, стремление русифицировать их нацию. Почти по каждому пункту предложения министра финансов сенат выдвинул свои возражения. Так, например, утверждалось, что дополнительных мероприятий для водворения в край русских денег не требуется, так как русская монета принимается в платежах, но пользуются этим почти исключительно в Выборгской губернии, а в этой губернии русских денег достаточно благодаря торговле на границе. Русские промышленники же и торговцы приобретают право финляндского гражданства, поэтому $§ 2$ Устава Финляндского банка о том, что банк может учитывать векселя лишь в финской марке, акцептированные проживающими в крае финляндскими гражданами, не мешает их кредитовать. Тем не менее сенат сообщил, что готов к будущему сейму (заседанию парламента) составить проект о дополнении этого параграфа, чтобы могли быть учитываемы также векселя не имеющих финляндского гражданства российских купцов и промышленников. Был сформулирован и передан сенату список банковских операций, которые предполагались производиться в новом отделении, а именно:

- у учет векселей с двумя подписями и других срочных обязательств;

- ссуды под товары и документы на них;

- $\quad$ ссуды под русские и финляндские государственные и ипотечные процентные бумаги;

- прием денежных вкладов на хранение;

- покупка и продажа векселей;

- перевод сумм и другие комиссионные операции;

- операции за счет Государственного казначейства [8, л. 11-13].

Сенат сообщил, что предполагаемая деятельность отделения подразумевает операции, относящиеся к банковскому делу в прямом смысле слова, а в Высочайших постановлениях от 10 мая 1886 г. о банковских операциях говорится, что банковские предприятия, имеющие целью вклады и выпуск облигаций на территории Фин- ляндии, могут быть учреждены лишь в самой Финляндии, а все члены правления должны быть финляндскими гражданами. Денежные же операции без приема вкладов могут на установленных в Постановлении от 31 марта 1879 г. основаниях проводиться как финляндскими, так и проживающими в крае русскими или иностранными гражданами - но сенат настаивал, что в любом случае Постановления не предусматривают открытия на территории Финляндии такого государственного учреждения, как Государственный банк Российской империи. Поэтому до открытия отделения законодательство должно было быть дополнено при участии земских чинов (сейма) [8, л. 18-21]. Примечательно, что к этому отзыву финляндский генерал-губернатор Н. И. Бобриков приложил свою записку, в которой отметил, что не разделяет встреченных сенатом препятствий по распространению на Великое княжество Финляндское действий Государственного банка, не основанных, по его мнению, на бесспорных данных. «В деле достижения теснейшего объединения Финляндии с центром империи, - писал он, - несомненно, весьма важное значение имело бы установление связи экономической. Ввиду сего признавал бы скорейшее открытие в Гельсингфорсе отделения Государственного банка мерою не только желательною, но и крайне необходимою, вызываемою также и потребностью предстоящей монетной реформы» [8, л. 22-23]. Николай Иванович был известен и нелюбим в великом княжестве из-за своей «русификаторской» и «объединительной» политики, проводимой им последовательно и жестко. В 1904 г., незадолго до открытия в Гельсингфорсе первого отделения Государственного банка, за которое он так ратовал, он был убит финским террористом. Бобриков стал единственным финляндским генерал-губернатором, закончившим свою карьеру таким печальным образом.

Дальнейшие консультации с финляндским сенатом не проводились. Рекомендация сената вынести вопрос об изменении банковского законодательства на заседание сейма означала затягивание решения вопроса на неопределенное время. Руководствуясь тем, что устав Государственного банка как закон общегосударственный отменяет при несоответствии с местным законодательством все несогласные с ним положения, статс-секретарь В. К. Плеве, представитель великого княжества в Петербурге, отправил императору доклад о необходимости открытия 


\section{Исторический журнал: научные исследования № 4 (34) • 2016}

DOI: $10.7256 / 2222-1972.2016 .4 .19734$

в Гельсингфорсе, а затем по мере надобности и в других городах Великого княжества Финляндского отделений Государственного банка Российской империи [8, л. 24-27].

18 декабря 1903 г. вышло высочайшее постановление об открытии в Финляндии отделений Государственного банка [8, л. 32]. Однако из-за неспокойного положения в великом княжестве и явно неодобрительного отношения в финских кругах к учреждению Государственного банка - в частности, в сенате - открытие отделения замедлилось и состоялось лишь 1 августа 1905 г., а Министерство финансов ограничило его операции очень узким кругом возможностей, причем главная банковская операция - учет векселей - вовсе не была ему предоставлена. Последнее обстоятельство с самого начала поставило Гельсингфорское отделение в условия, исключающие возможность широкой влиятельной и выгодной деятельности, которая на практике свелась практически только к переводной операции. Но хотя кредитов русские купцы на «общеимперских» условиях, как изначально планировалось, и не смогли брать, проблема с обменом марок на рубли, на которую жаловались в письме генералгубернатору, была решена. Вместе с тем обнаружилось, что переводная операция приносит пользу не только русской торговле в Финляндии, но также и спекулянтам. Падение российского вексельного курса на мировом рынке в 1906 г., вызванное неуспешной войной и внутренними беспорядками, привело к спекуляции на рыночном курсе рубля при фиксированном курсе, по которому меняли в отделении [9, л. 33].

Ввиду этих обстоятельств министр финансов и генерал-губернатор пришли к решению приостановить действие отделения, и 16 августа 1906 г. вышел указ о его временном закрытии [8, л. 63-64].

Так завершился первый этап, выявив основные сложности интегрирования Финляндии в сферу банковского влияния России - в первую очередь проблемы с местным банковским законодательством. Государственный банк мог обойти его, так как устав Государственного банка считался общегосударственным, но при этом терял значительную часть своей выгоды, существенно ограничив операции отделения, а для российских частных банков это и вовсе стало серьезной преградой.

Еще в 1904 г., до официального открытия в Гельсингфорсе отделения Государственного банка, в Министерство финансов поступила прось- ба от Русского для внешней торговли банка об открытии отделения этого частного банка в Финляндии $[10$, л. 1]. Генерал-губернатор Великого княжества Финляндского, к которому с этим запросом обратился и. о. министра финансов, счел его несколько несвоевременным - сперва стоило разобраться с открытием отделения Государственного банка. Однако в целом он инициативу поддержал и послал в статс-секретариат великого княжества просьбу передать императору предложение издать высочайшее повеление о том, чтобы членами правления банка могли быть все русские подданные, а не только финляндские граждане [10, л. 2-5]. В июне 1904 г. император повелел финляндскому сенату до 1 декабря 1904 г. выработать два проекта:

- постановления о порядке и условиях открытия в Финляндии отделений русских частных банков;

- закона о представлении всем русским подданным одинаковых с финляндскими гражданами прав по занятию в крае всеми видами торговой и промышленной деятельности [10, л. 6-11].

Однако к декабрю 1904 г. эти законопроекты выработаны не были - в стране обострилась внутриполитическая ситуация, в 1905 г. в Финляндии началась всеобщая забастовка, приведшая в том числе к реорганизации сената, - и к вопросу вернулись только в 1910 г. Директор правления на этот раз Санкт-Петербургского городского кредитного общества обратился с ходатайством о распространении своих операций ипотечного кредитования на территорию Финляндии и, в частности, на Выборгскую губернию $[11$, л. 18$]$. Это заставило председателя Совета министров напомнить генерал-губернатору о так и не исполненном в 1904 г. императорском повелении сенату. В течение трех лет, с марта 1910 по февраль 1913 гг., канцелярия генерал-губернатора посылала в сенат запросы (в общей сложности 12 штук) по поводу выработки законопроектов о русских частных банках, но безуспешно [11, л. 1-11]. Только в апреле 1913 г. хозяйственный департамент финляндского сената предоставил первоначальный проект постановления о порядке и условиях открытия в Финляндии отделений русских частных банков (вопрос о представлении всем русским подданным одинаковых с финляндскими гражданами прав по занятию в крае всеми видами торговой и промышленной деятельности к тому моменту уже был решен законом от 20 января 1912 г. об 


\section{Экономическая история, история предпринимательства}

уравнении в правах с финляндскими гражданами других русских подданных) [11, л. 23-32]. В течение года проект прошел правки генералгубернатора, был обсужден и утвержден на заседании Совета министров в ноябре 1913 г. по соглашению министра финансов с министром юстиции, финляндским генерал-губернатором и министром - статс-секретарем Великого княжества Финляндского [11, л. 55-60].

Параллельно с утверждением законопроекта о частных русских банках был возобновлен вопрос об открытии в Финляндии отделения Государственного банка. В 1911 г. генерал-губернатор $\Phi$. А. Зейн счел, что ситуация в великом княжестве за прошедшие годы переменилась к лучшему и пришло время вновь приступить к практическому исполнению высочайшего повеления от 5 декабря 1903 г. об открытии учреждений Государственного банка в Финляндии. При этом чтобы деятельность отделения могла быть успешной, генерал-губернатор настаивал на том, чтобы распространить ее на все предусмотренные уставом банка операции. По мнению финляндского генерал-губернатора, последствия этой меры могли бы быть плодотворными не только в политическом отношении, способствуя укреплению в Финляндии русского влияния и теснейшему ее сближению с другими частями империи, но и в экономическом отношении. В первую очередь следовало, по его мнению, открыть отделения банка в Гельсингфорсе и Выборге. Председатель Совета министров П. А. Столыпин поддержал мнение генерал-губернатора и, препроводив его письмо министру финансов, высказался о желательности и целесообразности осуществления его предположений. В ответном письме министр финансов уведомил Столыпина, что со своей стороны не имеет принципиальных возражений при условии, однако, если опасения недоброжелательного отношения к учреждению Государственного банка со стороны финского населения представляются несущественными. Столыпин ответил, что, не отрицая возможности бойкота учреждений банка со стороны местных жителей, он считает, тем не менее, крайне желательным приступить к открытию учреждений Государственного банка в Финляндии, начав с города Выборга, который может обеспечить будущему отделению русскую клиентуру даже независимо от финского населения [9, л. 35].

Совет Государственного банка же, рассмотрев этот вопрос, вынес решение, что откры- тие отделения банка в г. Выборге должно благоприятно отразиться на русской торговле в Финляндии, предоставив возможность русским торговцам пользоваться доступным и дешевым кредитом на условиях Государственного банка. Кроме того, проектируемая мера предположительно могла оказать влияние на понижение существовавшего в Финляндии высокого учетного процента, что в свою очередь благоприятно бы отразилось на экономической жизни края, дав толчок к дальнейшему его развитию.

В мае 1912 г. было созвано Особое совещание из представителей министерств финансов и юстиции, финляндского генерал-губернатора и статс-секретаря Великого княжества Финляндского для обсуждения вопросов правового характера. На нем было принято решение первоначально ограничить операции банка учетом векселей с двумя подписями и других срочных обязательств, ссудами под государственные и ипотечные процентные бумаги, покупкой и продажей векселей и других ценностей, переводом сумм и других комиссионных операций за счет государственного казначейства. Все расчеты банка утвердили производить в финляндской валюте [9, л. 33-43].

В августе 1913 г. был сформирован учетный комитет отделения. В финской периодике того времени отмечалось, что наиболее видные русские купцы отказались в нем участвовать, так как находились в деловых отношениях с финляндскими банками [12, л. 21]. В конце декабря состоялось его торжественное открытие.

Новоназначенный управляющий Выборгским отделением отправлял свои доклады как управляющему Государственным банком, так и генерал-губернатору. По этим докладам видно, что главной своей задачей управляющий отделением считал информирование об экономических процессах в крае и предложение дальнейших перспектив как отделения, так и финансовой политики империи в целом. В своих докладах генерал-губернатору он обозначил основные проблемы развития в Финляндии деятельности Государственного банка.

«Общественное мнение, что Финляндия богата - “оптический самообман”, - писал управляющий весной 1914 г., - оборотные средства настолько ограничены, что и крестьянин, и землевладелец, и промышленник почти не финансируются банками, находя необходимые средства лишь у частных лиц за весьма высокий процент» [13, л. 7]. Банками, по его мнению, 


\section{Исторический журнал: научные исследования № 4 (34) • 2016}

\section{DOI: $10.7256 / 2222-1972.2016 .4 .19734$}

финансировалась лишь вся импортная немецкая торговля, что давало обширные возможности для мелкого кредита. Однако отделению на тот момент из кредитных операций была разрешена лишь учетно-вексельная. Управляющий отделением считал, что в дальнейшей перспективе необходимо расширить операции по открытию кредита, так как с самого открытия в отделение поступало значительное количество заявлений на него, а также начать принимать вклады, нужда в которых тоже ощущалась, особенно среди воинских частей российской армии, расположенных в Выборге.

По поводу проектировавшегося в правительстве таможенного объединения с Финляндией, которая на тот момент имела собственную таможенную службу, в том числе и на границе с Россией, управляющий отделением писал, что «пока все таможенные аномалии не будут устранены, помещение здесь имперских капиталов должно быть признано почти недопустимым, так как такое помещение есть перекачивание через Финляндию без великой пользы для России имперских капиталов на заграничные рынки, давая этим в итоге лишь барыши финляндскому банку» [13, л. 7-10].

Помимо этого, по его мнению, Государственный банк стал бы нормально функционировать на территории великого княжества только после установления там рубля как единого расчетно-денежного знака, так как ввиду колебания курса рубля он находился в некотором подчинении у марки и служил скорее предметом спекуляции. К примеру, по словам управляющего, за два месяца деятельности отделения из Выборга в империю было переведено около 1 млн рублей, однако это не было результатом торговых оборотов с Финляндией. Эти суммы были переведены местными банками русским частным банкам в Петербург в покрытие платежей, произведенных последними за муку, приобретенную Финляндией в Германии, а также за покупку финскими банками за границей русских же рублей во время падения там российского вексельного курса, то есть, казалось бы, финляндское золото определилось на имперский баланс, но на самом деле оно тотчас же ушло за границу, оставив лишь осадок от спекуляций с рублем финским банкам.

Если учесть, сколько сложностей вызвало и сколько времени заняло открытие этого отделения, неудивительно, что подготовка таких реформ, как таможенное и денежное объедине- ние, которые могли привести к кардинальным изменениям, заняла не одно десятилетие. Открытие отделений русских банков изначально задумывалось как мера, которая подготовила бы почву для денежной реформы. Но в итоге оказалось, что для нормальной, экономически выгодной работы отделения Государственного банка в Финляндии эти реформы были необходимы, потому что без них российский рубль использовался в финансовых операциях княжества лишь как предмет спекуляции, а российские капиталы уходили на заграничные рынки, не принося прибыли казне империи.

Из затруднений отделения Государственного банка видно, что условия для частных русских банков в Финляндии были не менее, но более сложными - многие так и не решились открыть там свои отделения.

Несомненно, что основным препятствием для более тесного сближения, в том числе финансового, России и Финляндии стало негативное к этому отношение финского общества. Во второй половине XIX в. в Финляндии начался расцвет национального самосознания, и для национальной идеи право на собственную валюту, к примеру, имело немаловажное значение. Одна финляндская газета написала по поводу открытия отделения Государственного банка: «Конечно, от финансового учреждения может быть для местного общества временная польза, но может случиться в конце концов и то, что придется лишиться и денег, и кошелька. Мы во всяком случае не могли бы поверить в возможность того, что финляндское общество обнаружит себя таким алчным до золота, что станет связывать себя и свои свободы русским рублем, как бы соблазнительно он ни звучал» [12, л. 35]. Всякая экономическая зависимость, по словам статьи из другой финляндской газеты, от русских интересов являлась бы опасностью для финляндского национального бытия [13, л. 53].

Тем не менее не все финны разделяли эту точку зрения. Спрос на деньги в Финляндии в то время, как и писал управляющий Выборгским отделением, был действительно велик, и в апреле 1914 г. финляндская газета HBL опубликовала гневную статью о том, что «соблазн удобного кредита для некоторых оказался не под силу». Разоблачался некий крупный финский землевладелец, обратившийся в Выборгское отделение Государственного банка за крупной ссудой под залог недвижимости [13, л. 52]. Когда скандал разгорелся сильнее и достиг российских газет, 


\section{Экономическая история, история предпринимательства}

DOI: $10.7256 / 2222-1972.2016 .4 .19734$

в «Новой газете» опубликовали заявление управляющего отделением, что такие ходатайства поступали еще до открытия отделения и продолжают поступать в количестве несколько десятков ежедневно, но Государственный банк отказывает в выдаче долгосрочных займов под залог недвижимости и учитывает лишь краткосрочные векселя [13, л. 55].

Из отчета управляющего Выборгским отделением за первые два месяца после открытия отделения видно, что финны, как минимум, не игнорировали новое отделение - было открыто 26 кредитов на сумму 448,5 тыс. рублей, из них 8 русским на 291 тыс. руб., 12 финнам на 79,5 тыс. руб. и 6 евреям на 78 тыс. руб. [13, л. 12].

К 1914 г. 75\% оборотов выборгской торгово-отпускной торговли производилось русским купечеством, но тем не менее оно за единичными исключениями не прибегало в первые месяцы функционирования отделения к его услугам, продолжая кредитоваться в финляндских банках. Последние были особо заинтересованы в русских клиентах с векселями на руках и являющихся там местными банковскими акционерами и членами советов. Управляющий Выборгским отделением вначале решил, что «именно русское купечество является здесь более финляндцами, чем финны», но позже понял, что пока купцам было выгодно финансироваться у финских банков, они придерживались их политических взглядов. Финляндский банк, чтобы не потерять русское купечество, понизил учетный процент накануне дня открытия отделения в первый раз, а во второй раз - накануне понижения императорского учетного процента в марте 1914 г. Кроме того, Финляндский банк стал предоставлять всевозможные льготы более мелкому русскому купечеству, которое до открытия отделения совершенно им не финансировалось (тут можно вспомнить проблемы русского купечества в 1901 г., когда оно жаловалось генерал-губернатору на притеснение со стороны финляндских банков, отказывающих ему в кредите - хотя, конечно, в Выборге отношение к русским всегда было мягче). Но управляющий отмечал, что «люди, в делах Финляндского банка сведущие, утверждают, что его баланс ни в коем случае не давал права на производство мартовского понижения, показателем чего является то обстоятельство, что част- ные банки постепенно сокращают круг обслуживаемых ими лиц, о чем мне лично приходится неоднократно слышать от посещающих отделение туземцев, заявляющих, что в гельсингфорских и прочих финляндских банках оборотные средства приобретаются все с прогрессивно увеличивающимися затруднениями» [13, л. 17].

Из этого видно, что Центральный банк Финляндии боролся за свою сферу влияния, оценивая отделение Государственного банка Российской империи как жизнеспособного конкурента.

Выборгское отделение Государственного банка просуществовало вплоть до декабря 1917 г., когда Финляндия отделилась от России, но основные годы его существования пришлись на Первую мировую войну, когда России уже было не до упрочения своего финансового влияния на финскую окраину. Политика интегрирования Финляндии в экономическую сферу Российской империи, в русле которой открывались отделения Государственного банка, проводилась последовательно, но с большими задержками, объясняемыми тем, что не всегда была возможность уделять ей достаточно средств и внимания. Экономически интегрировать Финляндию с помощью финансовых рычагов представлялось, вероятно, самым безболезненным способом, но он требовал значительных капиталовложений. С открытия первого же отделения стало понятно, что экономически выгодным оно станет нескоро. Управляющий же вторым отделением прямо указал, что необходимо провести немалые изменения в княжестве, прежде чем Государственный банк перестанет нести в нем убытки. Все планируемые для этих изменений реформы (денежная, таможенная) по сути должны были свести автономию Финляндии к минимуму, что могло бы породить значительные волнения в крае. Однако отделение в Выборге выявило и значительный спрос на кредит и денежные средства в Финляндии. Несмотря на негативное настроение определенных кругов финляндского общества, Великому княжеству было экономически выгодно вливание российского капитала, а потому курс на финансовое интегрирование без прямой конфронтации, но с значительными денежными вливаниями мог иметь перспективы.

Библиография:

1. Бородкин М. М. Краткая история Финляндии. СПб.: Т-во Р. Голике и А. Вильборг, 1911. 200 с.

2. Расила В. История Финляндии. 2-е изд., перераб. и доп. Петрозаводск: Издательство ПетрГУ, 2006. 360 с. 


\section{Исторический журнал: научные исследования № 4 (34) • 2016}

DOI: $10.7256 / 2222-1972.2016 .4 .19734$

3. Арола М. Кредитный риск финского правительства и «российские премии» (1863-1938 гг.) // Экономическая история: ежегодник / Центр экономической истории при историческом факультете МГУ имени М. В. Ломоносова [и др.]. М.: РОССПЭН, 2007. С. 550-551.

4. Анисимова Д. В. Неизвестная фондовая биржа Российской империи. О заключительном этапе экономической автономизации Великого княжества Финляндского // Экономическая история. 2011. № 1. С. 48-60.

5. Бобович И. М. Русско-финляндские экономические отношения накануне Великой Октябрьской социалистической революции. Л.: Издательство Ленинградского университета, 1968. 192 с.

6. Ананьич Б. В. Золотой стандарт в Финляндии и России: финансовый аспект имперской политики // Россия на рубеже XIX-XX веков: Материалы научных чтений памяти проф. В. И. Бовыкина, Москва, МГУ имени М. В. Ломоносова, 20 января 1999 г. М.: РОССПЭН, 1999. С. 115-124.

7. Правилова Е. А. Финансы империи: Деньги и власть в политике России на национальных окраинах, 1801-1917. М.: Новое издательство, 2006. 453 с.

8. Учреждение Гельсингфорской конторы Государственного банка, 1904 г. // Национальный архив Финляндии. Фонд канцелярии финляндского генерал-губернатора. Д. 15-2.

9. Статс-секретариат Великого княжества Финляндского // Российский государственный исторический архив. Ф. 1361. Оп. 1. Д. 107.

10. Открытие в Гельсингфорсе русского для внешней торговли банка, 1904 г. // Национальный архив Финляндии. Фонд канцелярии финляндского генерал-губернатора. II отдел. Раздел IV. Д. 15-3.

11. О порядке и условиях открытия в Финляндии отделений русских частных банков, 1910 г. // Национальный архив Финляндии. Фонд канцелярии финляндского генерал-губернатора. II отдел. Д. 36.

12. Об открытии в Финляндии отделения Государственного банка, 1911 г. // Национальный архив Финляндии. Фонд канцелярии финляндского генерал-губернатора. II отдел. Д. 26.

13. О деятельности отделения Государственного банка в г. Выборг, 1914 г. // Национальный архив Финляндии. Фонд канцелярии финляндского генерал-губернатора. II отдел. Д. 37.

References (transliterated)

1. Borodkin M. M. Kratkaya istoriya Finlyandii. SPb.: T-vo R. Golike i A. Vil'borg, 1911. 200 s.

2. Rasila V. Istoriya Finlyandii. 2-e izd., pererab. i dop. Petrozavodsk: Izdatel'stvo PetrGU, 2006. 360 s.

3. Arola M. Kreditnyi risk finskogo pravitel'stva i «rossiiskie premii» (1863-1938 gg.) // Ekonomicheskaya istoriya: ezhegodnik / Tsentr ekonomicheskoi istorii pri istoricheskom fakul'tete MGU imeni M. V. Lomonosova [i dr.]. M.: ROSSPEN, 2007. S. 550-551.

4. Anisimova D. V. Neizvestnaya fondovaya birzha Rossiiskoi imperii. 0 zaklyuchitel'nom etape ekonomicheskoi avtonomizatsii Velikogo knyazhestva Finlyandskogo // Ekonomicheskaya istoriya. 2011. № 1. S. 48-60.

5. Bobovich I. M. Russko-finlyandskie ekonomicheskie otnosheniya nakanune Velikoi Oktyabr'skoi sotsialisticheskoi revolyutsii. L.: Izdatel'stvo Leningradskogo universiteta, 1968. $192 \mathrm{s.}$

6. Anan'ich B. V. Zolotoi standart v Finlyandii i Rossii: finansovyi aspekt imperskoi politiki // Rossiya na rubezhe XIX-KhKh vekov: Materialy nauchnykh chtenii pamyati prof. V. I. Bovykina, Moskva, MGU imeni M. V. Lomonosova, 20 yanvarya 1999 g. M.: ROSSPEN, 1999. S. 115-124.

7. Pravilova E. A. Finansy imperii: Den'gi i vlast' v politike Rossii na natsional'nykh okrainakh, 1801-1917. M.: Novoe izdatel'stvo, 2006. $453 \mathrm{~s}$.

8. Uchrezhdenie Gel'singforskoi kontory Gosudarstvennogo banka, 1904 g. // Natsional'nyi arkhiv Finlyandii. Fond kantselyarii finlyandskogo general-gubernatora. D. 15-2.

9. Stats-sekretariat Velikogo knyazhestva Finlyandskogo // Rossiiskii gosudarstvennyi istoricheskii arkhiv. F. 1361. Op. 1. D. 107.

10. Otkrytie v Gel'singforse russkogo dlya vneshnei torgovli banka, 1904 g. // Natsional'nyi arkhiv Finlyandii. Fond kantselyarii finlyandskogo general-gubernatora. II otdel. Razdel IV. D. 15-3.

11. O poryadke i usloviyakh otkrytiya v Finlyandii otdelenii russkikh chastnykh bankov, 1910 g. // Natsional'nyi arkhiv Finlyandii. Fond kantselyarii finlyandskogo general-gubernatora. II otdel. D. 36.

12. Ob otkrytii v Finlyandii otdeleniya Gosudarstvennogo banka, 1911 g. // Natsional'nyi arkhiv Finlyandii. Fond kantselyarii finlyandskogo general-gubernatora. II otdel. D. 26.

13. O deyatel'nosti otdeleniya Gosudarstvennogo banka v g. Vyborg, 1914 g. // Natsional'nyi arkhiv Finlyandii. Fond kantselyarii finlyandskogo general-gubernatora. II otdel. D. 37. 